\title{
CSÍKI SZÉKELY MÚZEUM
}

Csíki Székely Múzeum

Cím: Csíkszereda, Vár tér 2.

Honlap: https://www.csikimuzeum.ro

E-mail: info@csikimuzeum.ro

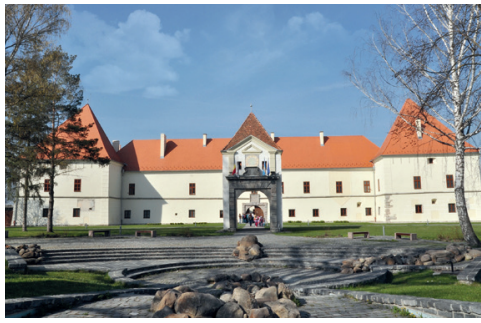

Csíkszeredában már a 19. század vége felé foglalkoztatta az értelmiséget egy helyi múzeum létrehozása: „hol úgy a régi idők emlékei, mint a jelen eredményei a jövő nemzedékek okulására összegyújtessenek". ${ }^{1}$ 1876. január 9-én, Tivai Nagy Imre elnökletével, megalakult a Csíki Székely Múzeum Egylet, de a múzeum létrehozása nem történt meg. Vitos Mózes a Csíkmegyei Füzetekben, ${ }^{2}$ Herrmann Antal néprajzkutató, kolozsvári egyetemi tanár a Csíki Lapokban fogalmazta meg egy múzeumi intézmény szükségességét. ${ }^{3}$ Utóbbi még azt is pontosította, hogy milyen szakosztályokból kellene, hogy álljon a létrehozandó múzeum. A törekvések ellenére azonban a tervek még sokáig nem valósultak meg.

1925-ben a csíkszeredai törvényszék másodszorra is bejegyezte a Csíki Múzeum és Kultúregyletet. Az egylet bejegyzése, vagyis az 1876-os egyesületalapítás megújítása, a húszas években elkezdődött székelyföldi népi mozgalmak része volt. 1929-ben Domokos Pál Péter népmúvészeti kiállítást rendezett a csíkszeredai Római Katolikus Főgimnáziumban, amely előőrse volt a következő évi nagy eseménynek. 1930 júniusában ugyanis Domokos Pál Péter tanár-néprajzkutató, Nagy Imre csíkzsögödi festőművész és Vámszer Géza tanár-néprajzkutató gyakorlati irányításával, valamint Gál Ferenc tanító és mások segédletével végre elkészült a hasonló nevet viselő egyesület által alapított Csíki Székely Múzeum első kiállítása Csíksomlyón, a Stabilimentben. ${ }^{4}$ Több mint 140 egyház- és képzőmúvészeti, valamint néprajzi tárgyat állítottak ki 14 teremben. A frissen alakult múzeum azonban székhelyet, épületet nem kapott, és a létrehozott gyűjtemény sok évig különböző épületekben vagy padlásokon kallódott. (Néhány évig Vámszer Géza felvigyázta a gyüjteményt).

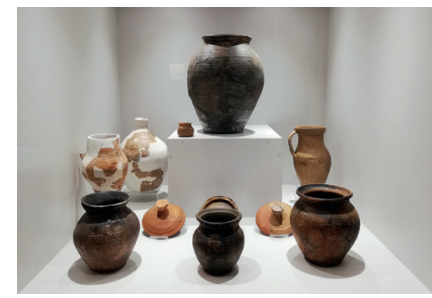

${ }_{1}$ Megyei muzeum. = Csiki Lapok, 10. évf. 44. sz. 1898. 2. p.

2 VITOS Mózes: Csikmegyei füzetek II. Adatok Csikmegye leirásához és történetéhez. [Reprint]. Csíkszereda, Hargita Kiadóhivatal, 2003.

3 HERRMANN Antal: Csikmegyei muzeum I. = Csiki Lapok, 14. évf. 1. sz. 1902. 1-2. p.; HERRMANN Antal: Csikmegyei muzeum II. = Csiki Lapok, 14. évf. 3. sz. 1902. 2. p.; HERRMANN Antal: Csikmegyei muzeum III. = Csiki Lapok, 14. évf. 7. sz. 1902. 2. p.; HERRMANN Antal: Csikmegyei muzeum IV. = Csiki Lapok, 14. évf. 12. sz. 1902. 2. p.

${ }^{4}$ Csíkszék egykori székháza, rezidenciája, más néven pretórium, ma tüdőkórháznak ad helyet. 
1946-ban Kovács Dénes festőmúvész és rajztanár, majd múzeumigazgató, önkéntesen fogott hozzá a kallódó, porosodó alapgyújtemény újraleltározásához és a múzeumi intézmény megalapításához. A csíkszeredai múzeumot önálló intézményként 1950-ben hozták létre. Előbb rajoni, majd megyei múzeumkomplexum lett belőle, hogy aztán 1990 után felvegye az egykori, Csíki Székely Múzeum nevet. Az intézmény kezdetben (1940-es évek végétől) a mai Gál Sándor utcában, az ún. Dávid-szállóban, majd ugyanabban az utcában, a Zakariás-féle házban működött. 1970 után János Pál igazgató vezetésével a múzeumot átköltöztették a Mikó-várba, ahol jelenleg is múködik.

Az 1989-es romániai rendszerváltás után azonban a Csíki Székely Múzeumban is pozitív változások indultak el. 1994-ben a román Országos Múzeumi és Gyújteményi Bizottság elfogadta a múzeum régi-új nevét. Hargita Megye Tanácsa ugyancsak ebben az évben hagyta jóvá a Hargita Megyei Múzeumi Komplexum helyi múzeumi egységekre való szétválását, Csíkszereda Helyi Tanácsa pedig 1995. január 1-jei dátummal megalakította a Csíki Székely Múzeumot Csíkszereda székhellyel.

2003 augusztusától Gyarmati Zsolt a Csíki Székely Múzeum igazgatója. Irányítása alatt intenzívvé váltak a magyarországi intézményekkel való kapcsolatok, és jelentős képzőmúvészeti, történeti, régészeti és irodalomtörténeti (mega)kiállítások kaptak otthont a Mikó-várban: többek között Csontváry, Rippl-Rónai és Munkácsy festészete, Egyiptom müvészete a fáraók korában, A tatárjárás, Weöres Sándor 100 - a megmozdult szótár, Kallós Zoltán kiállítás, Elit alakulat 2.0 stb. 2004-től az intézmény saját évkönyvet jelentet meg A Csíki Székely Múzeum Évkönyve címmel (ennek folytatása lesz a Patina címú múzeumi magazin).

A múzeum néprajzi, régészeti, történeti, képzőművészeti és természettudományi gyűjteményei jelenleg összesen mintegy 145 ezer tárggyal rendelkeznek, amelyeknek folyamatos a feldolgozása. A Mikó-várbeli székhelyen öt nagy alapkiállításunk látogatható: Csíki idők járása (néprajz), Megmentett szakrális kincseink (restaurált tárgyak), a Csíksomlyói ferences nyomda, A Mikó-vár története (vártörténet), Útkereszteződésben-Csíkszereda város története (várostörténet) és külön Nagy Imre festészete (folyamatos tematikus kiállítások a csíkzsögödi Nagy Imre-galériában).

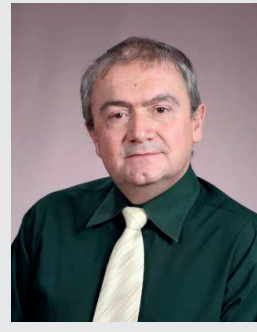

Málnási Levente

A kolozsvári Babeș-Bolyai Tudományegyetem bölcsészkarának magyar-néprajz szakán végzett 1996-ban. Több évig magyart és angolt tanított vidéki majd csíkszeredai iskolákban, később könyvtárosként is tevékenykedett. 2016-tól a Csíki Székely Múzeumban dolgozik mint néprajzos-muzeológus és múzeumi szakkönyvtáros. Szabadidejében néprajzkutatással és irodalommal foglalkozik. 